\title{
Does Servant Leadership Behavior Induce Positive Behaviors? A Conceptual Study of Servant Leadership, Psychological Safety and Turnover Intention
}

\author{
Noor Ahmed Brohi ${ }^{1 *}$, Amer Hamzah Jantan², Sultan Adal Mehmood ${ }^{1}$, Mansoor Ahmed Khuhro ${ }^{1}$, Muhammad \\ Saood Aktar ${ }^{1}$ \\ ${ }^{I}$ Putra Business School, University Putra Malaysia, Serdang Dahrul Ehsan Selangor 43400, Malaysia \\ ${ }^{2}$ Faculty of Economics and Management, University Putra Malaysia, Serdang Dahrul Ehsan Selangor 43400, Malaysia \\ *Corresponding authorE-mail: noorahmed.brohi@yahoo.com
}

\begin{abstract}
In this paper, we examine how servant leadership and psychological safety may enlighten our understanding of human mechanisms that affect follower outcomes. Servant leadership style as penned by Robert Greenleaf that servant leaders guide followers to adopt the behavior of their leaders by putting others needs above their own. From emerging research on servant leadership, we proposed a model contending that servant leaders increase employees' psychological safety that organization is a safe place to speak up ideas, opinions and take decisions, which directly influences Employees' turnover intention. As proposed, servant leadership will be negatively related to Employees' turnover intention and positively related to psychological safety. Psychological safety will mediate the relationship between servant leadership and turnover intention.
\end{abstract}

Keywords: Servant Leadership, Psychological Safety, Turnover Intention.

\section{Introduction}

This is a theory-driven study which examines how servant leadership and certain aspects of positive organizational behavior may affect follower's behavior and outcomes. In the current study, we extended the turnover research (e.g. Hom et al., 2017; Kashyap \& Rangnekar, 2016; Rodriguez, 2016) to specifically consider how theoretical and conceptual advances in servant leadership theory and psychological safety can enlighten our understanding of possible mechanisms that affect turnover intention.

The review of the literature on leadership styles shown that there are two distinct styles of leadership, transformation leadership style and servant leadership style, since few decades special attention has been given on producing people-oriented leadership style which is unique from other leadership styles (Bass \& Avolio, 1993; Greenleaf, 2002; Stone, Russell, \& Patterson, 2004; Parolini, Patterson, \& Winston, 2009). Stone et al. (2004) stated in their study conducted on college and organizational leadership that servant leadership and transformational leadership styles are equally vibrant.

Robert Greenleaf in 1977 in his early scholarship on servant leadership theory, proliferated the concept of servant leadership, in which he described servant leadership as a leadership style that focuses on the notion of "to serve, and to serve first". Subsequently, Greenleaf defines it as "leadership begins with the natural feeling that one wants to serve, to serve first. The conscious choice brings one to aspire to lead. That person is sharply different from one who is a leader first, perhaps because of the need to assuage an unusual power drive or to acquire material possessions". (p. 27)
Moreover, since the inception of servant leadership, a bunch of research have been carried to examine the unique characteristics of servant leadership style in different organizational contexts (Russell \& Stone, 2002; Spears, 2004; Shaw \& Newton, 2014). The findings have shown that leaders who gone through or adopted servant leadership behavior have a positive influence on organizational climate and employees' outcomes such as trust in leadership and overall performance (Joseph \& Winston, 2005; Black, 2010).

However, since its inception, there is a need to conduct more research to understand the nature of servant leadership and its applicability in different settings. Hence, more research is required at least two reasons: First, the past studies have focused mainly on transformational leadership style in organizational settings. Whereas, limited studies have investigated the role of servant leadership in organizational context because in its early day's servant leadership was used in the context of churches or religious settings. Therefore, little evidence found on servant leadership and the process through which it affects various follower and organizational outcomes. Moreover, the second reason is based on the suggestions given by Hoch, Bommer, Dulebohn, \& Wu (2016) which exhibited that as compared to other leadership styles, variance in employees' attitudes and behaviors was better explained by servant leadership. Furthermore, they also suggested to conduct more investigation on the impact of servant leadership style because servant leadership "as a stand-alone leadership approach that is capable of helping leadership researchers and practitioners better explain a broad range of outcomes".

Based on the above arguments and past studies, the current study aims to propose twofold contributions to further the scholarship on 
servant leadership literature and psychological safety- an intervening mechanism, literature. First, despite early call and empirical evidence of the worth of servant leadership in explaining follower outcomes, however, only very limited research works have conducted studies to examine the impact of servant leadership on employee turnover intention (Chiniara \& Bentein, 2016; Hoch et al., 2016). Thus, in the current study, we proposed that the leaders' servant leadership has an impact on turnover intention of employees.

In addition, the majority of the studies conducted till now only investigated the direct relationship between servant leadership and turnover intention, the underlying psychological mechanisms are almost ignored in the previous literature this is because of the fact that servant leadership is still in its early stages of empirical investigation and researchers have mainly worked on the construct clarification in last decades. (Chiniara \& Bentein, 2016, p. 1). Therefore, keeping in mind the limitations related to servant leadership research, it is important to investigate the psychological processes to understand the robustness of servant leadership construct and the influence it makes on follower outcomes such as turnover intention. Hence, to fill these gaps in the literature, the current study proposed that psychological safety- "individual's belief that workplace is safe to share personal views, ideas and take decisions" (Edmondson, 1999; Edmondson \& Lei, 2014), as the mediating factor between the relationship of servant leadership and turnover intention. The present study contends that servant leadership behavior induces psychological safety among employees', which in result mitigates the turnover intention.

Therefore, psychological safety affects the indirectly the relationship between servant leadership and turnover intention. Therefore, the current study proposes that this study will help to widen the prospect of the existing servant leadership and psychological safety literature and provides future directions to answer the call for future research and fill the gap in the literature.

\section{Servant Leadership}

Mahembe \& Engelbrecht, (2014), Lindahl, (2010) and Whitaker, (2009) described the concept of servant leadership throughout the process of propagating many characteristics of effective leadership. Leader qualities are predetermined by the philosophy or the set of principles and values which also helps in expanding the qualities of a leader too. A serious aspect of this study is to determine servant leadership impact on teacher retention.

Four decades ago, Robert K. Greenleaf penned his work which was titled as "Servant Leadership". In that, he termed that "a man's journey and his realization are the truest forms of leadership in which the leader has the utmost aspiration to serve others and help them to reach their true potential". Organizations following this legacy are robust and efficient (Spears, 2004).

Furthermore, Spears (2004) argued that the words servant and leader look like that they both are opposite to each other. However, it is also seen that people having service and supportive behavior or attitude, usually bring out sound potential and growth from others.

In addition, in their study on the contemporary human resource roles in the Malaysian context, Brohi et al., (2017) and Brohi et al., (2016) contended that manager play role of employee champion which means managers work for the betterment and well-being of employees. By relating this with leadership, a leader is expected to play the role of employee champion to enhance employees well-being, which lies at the core of servant leadership i.e. to serve followers and work for their overall well-being.

However, although in the context of organizational settings, the importance of servant leadership was stated by the initial studies on servant leadership, yet very limited attention was given to serv- ant leadership by organizational researchers. In the recent years, a corporate scandal involving huge companies (e.g., WorldCom, Enron, and Tyco wherein serious unethical practices were demonstrated at the senior leadership level in organizations) emphasized the need to study the moral/ethical values in the organizational context at the leadership level (Hoch et al., 2016). Earlier in the last decade, the studies conducted to develop scales to measure the servant leadership construct based on characteristics of servant leadership (Barbuto \& Wheeler, 2006; Liden, Wayne, Zhao, \& Henderson, 2008; Reed, Vidaver-Cohen, \& Colwell, 2011; van Dierendonck \& Nuijten, 2011). However, Liden et al. (2008), seven dimensions scale (i.e., "empowering, conceptual skills, creating value for community, putting subordinates first, helping subordinates grow and succeed, ethical behave, and emotional healing") is the widely used scale to measure servant leadership in organizational settings (Chiniara \& Bentein, 2016). Moreover, recently, Liden et al., (2015) developed the short version of the original 28-items servant leadership scale and calls for the validation of the shorter version in a different context. The short version servant leadership scale consists of 7-items. Therefore, the present study proposes the short version servant leadership scale to be used in future studies to investigate the servant leadership and its impact on follower outcomes.

\section{Turnover Intention}

Turnover intention remains an issue for 100 years (Hom et al., 2017). Despite so many studies conducted to curb the issue of turnover intention but the problem persists. The recent report on strategic human resource management showed that turnover intention is a leading challenge for the top organization. The turnover rate is almost doubled from $25 \%$ to $45 \%$ in three years' time only from 2013 to 2016 (SHRM, 2016). Therefore, as a leading challenge, turnover phenomenon necessitates more investigation to understand why people leave their organizations and the factors which retain employees. Turnover intention refers to the "individual's approximation of the chance of quitting his job in the near future" (Porter, Steers, Mowday, \& Boulian, 1974).

Previous researchers discussed the behavioral factors such as employees search intention for new jobs, or actual leave decision in order to understand the turnover phenomena among employees (Griffeth, Hom, \& Gaertner, 2000). Saood, Salleh, \& Mehmood, (2017) argued in their study that, as commonly intention to stay and intention to leave are used interchangeably, are two distinct concept which answers two different things. Thus, we focus only on the intention to leave or turnover intention construct. Furthermore, previous studies revealed that turnover intention is dependent on other components which means turnover intention is the outcome of some other factors which may lead towards this negative behavior thus these factors may be included in the turnover model which is suggested by Cotton \& Tuttle, (1986). In view of the above argument, the present study proposed that employee turnover intention as an outcome variable and servant leadership and psychological safety as mitigating factors of turnover intention. Griffeth et al. (2000) stated in their study that employee's intent to leave an organization is resulted by employees' job dissatisfaction. As a result, the dissatisfied employees lack the confidence to perform better and starts looking for other options and at the end leaves the organization. The dissatisfaction may be caused by lack of organizational support (Miskel, Fevurly, \& Stewart, 1979; Qureshi, Hamid, et al., 2018), leadership style (Brohi, Abdullah, et al., 2018; Qureshi, Brohi, et al., 2018), job satisfaction (Shah et al., 2018), organizational policies (Kossek \& Ozeki, 1998), organizational culture (Ahmed, Khuwaja, Brohi, \& Othman, 2018) career growth and psychological contracts (Akhtar, Salleh, Mahmood, Brohi, \& Ali, 2017) or perceived organizational support (Akhtar, Salleh, Ghafar, Khurro, \& Mehmood, 2018; Mehmood, Nadarajah, Akhtar, Brohi, \& Khuhro, 2018). Moreo- 
ver, servant leadership is found to be a key factor in mitigating the negative workplace outcomes (Hunter et al., 2013). Based on the above-mentioned discussion and arguments, the following has been proposed:

Proposition 1: There will be a negative relationship between Servant leadership and turnover intention.

\section{Psychological Safety (A Form of Positive Organizational Behavior)}

Psychological Safety refers to the "individual's self-belief about the workplace that it is safe to take the interpersonal risk, speak up the ideas, share opinions and act independently on key decisions" (Edmondson, 1999). Psychological safety was first introduced by Schein and Bennis (1965) in the context of organizational science almost five decades ago. However, it is in recent years when attention was given to psychological safety and empirical studies carried out to investigate its impact on follower outcomes. Past studies on psychological safety in organizational settings contended that it gives employees sense "to feel safe at work in order to grow, learn, contribute, and perform effectively in a rapidly changing world" (Edmondson \& Lei, 2014). In addition, considering the essential role played by psychological safety at the workplace, Kahn, (1990) suggested that leadership behavior may predict the employee's psychological safety.

Those employees who are prone to be humiliated when they take any decision or share their viewpoints at the workplace are less likely to perform at their fullest. In this regard, Psychological safety provides a sense of safety that employees will be treated fairly, they will not be humiliated or punished for taking decisions or on suggestions or ideas on issues related to the workplace, rather their actions will be supported and appreciated. This appreciation results in increased trust and increased respect between leadership and followers. This lies at the core of the servant leadership that by serving the needs of followers, showing empathy to them, empowering them and showing ethical behavior, servant leaders can increase followers trust in leaders and enhance follower's psychological safety (Kashyap \& Rangnekar, 2016; Krog \& Govender, 2015). Therefore, how employees are treated by servant leadership is an essential behavior to increase follower's positive organizational behavior-psychological safety.

Developing on the above-mentioned arguments and findings from past studies, it is anticipated that the supervisor's servant leader behavior will increase employees' sense of feeling safe at the workplace. Hence, the following is proposed:

\section{Proposition 2: There will be a positive relationship between} servant leadership and psychological safety.

The servant leader behavior enhances an employee's psychological safety which give employees the confidence to show their strengths and potential at the workplace without the fear of negative consequences or punishments. As a result, employees show positive behaviors and reciprocate the servant leadership behavior by adopting ethical behaviors, work engagement, organizational commitment and which ultimately results in high performance and increased levels of job satisfaction and intentions to stay in the organization. The change in basic assumptions of power relationship from employer to employees makes it more difficult to retain the best breeds of employees than ever before. The ever-changing trends make it challenging for employers to retain the best employees (Brohi, Jantan, Sobia, Akhtar, \& Pathan, 2018; Dries, 2013). Therefore, it is important to understand the factors that aid in mitigating the employee's turnover intention and enhance employee's intention to stay. The satisfied, engaged, committed, and fairly treated employees are more likely to stay in the organization. Thus, building upon the above arguments and findings from past studies, the following is proposed:
Proposition 3: There will be a negative relationship between psychological Safety and turnover intention.

\section{The Mediating Role of Psychological Safety}

Based on the theoretical and nomological network of psychological safety, it is logical to propose an indirect relationship of psychological safety between servant leadership and turnover intention. Psychological safety as an indirect effect mitigates the negative follower outcomes such as turnover intention. The leadership behavior is found to be a strong antecedent of psychological safety and psychological safety being a positive organizational behavior reduces negative outcomes at the workplace. Therefore, building upon servant leadership theory (Greenleaf, 1970), it can be assumed that servant leadership creates a serving culture at the workplace by showing serving nature towards followers. In return, followers adopt the serving culture and they themselves become servant followers. This relationship between leadership and followers increases followers trust in leadership and which in return provides psychological safety to followers. Moreover, the social exchange theory (Blau, 1964) explained that the servant leadership enables the development of employees' psychological safety and in exchange of this positive behavior displayed by leadership, followers reciprocate the servant leader behavior and engage in positive organizational behaviors such as job satisfaction, and employee's performance which eventually reduces turnover intention. Based on the arguments developed above, the following has been proposed:

Proposition 4: There will be an indirect effect of psychological safety between the relationship of servant leadership and turnover intention.

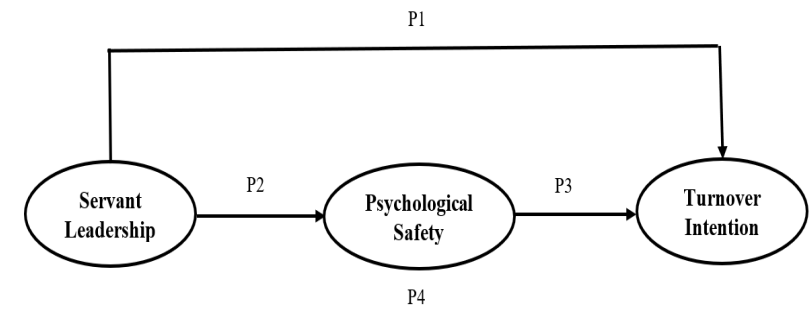

Fig.1: Conceptual model linking Servant Leadership, Psychological Safety and Turnover Intention

\section{Future Research Directions}

In the present study, the authors proposed significant directions for future research building upon dimensions and reveal more novel dimensions of servant leadership. Combinedly, the academic research and the development of the construct measurements of servant leadership and psychological safety seen rapid growth in the last decade. Both constructs are well defined and explained and are well grounded in positive psychology. More research is required to fully understand the nature of both constructs and antecedents and consequences of both constructs may be investigated to better operationalize the constricts in management science research. Therefore, this study represents an innovative and potentially important development in organizational science to evaluate the impact of servant leadership and psychological safety on follower outcome i.e. turnover intention.

\section{Conclusion}

The change in the organizational attitudes and behaviors ensures the presence and development of servant leader behavior in the organizations. The leaders are the binding forces of organization which binds organizations together to work as a community pursu- 
ing mutual goals. The is the main objective of the leaders these days who are committed to take the organization to the new levels in terms of success and performance in the 21 st century.

Developing on the arguments discussed in the earlier sections and the future directions of servant leadership and psychological safety- a form of positive organizational behavior establishes the significance and application of the selected subject. While we have made significant progress in understanding what reduces the employees' turnover intention and how the servant leadership behavior impacts the employee attitude and behavior, proposed the underlying process which servant leadership decreases negative follower outcomes, there is much yet to be learned. Therefore, the propositions made in this study will provide a base for the organizations and enable them to take steps to develop and nurture servant leaders and help organizations to retain the best breed of employees to remain competitive in the business world.

\section{References}

[1] Ahmed, A., Khuwaja, F. M., Brohi, N. A., \& Othman, I. bin L. (2018). Organizational Factors and Organizational Performance: A Resource-Based view and Social Exchange Theory Viewpoint. International Journal of Academic Research in Business and Social Sciences, 8(3), 579-599. https://doi.org/10.6007/IJARBSS/v8i3/3951

[2] Akhtar, M. S., Salleh, L. M., Ghafar, N. H., Khurro, M. A., \& Mehmood, S. A. (2018). Conceptualizing the impact of perceived organizational support and psychological contract fulfillment on employees' paradoxi- cal intentions of stay and leave. International Journal of Engineering and Technology (UAE), 7(5), 9-14. https://doi.org/10.14419/ijet.v7i2.5.10045

[3] Akhtar, M. S., Salleh, L. M., Mahmood, S. A., Brohi, N. A., \& Ali, R. M. (2017). Pull and push impact of perceived career growth and psychological contract breach on employees' intentions of stay and leave, conceptualization of paradoxical outcomes. In INTERNATIONAL CONFERENCE ON ENGINEERING, TECHNOLOGIES AND APPLIED SCIENCES 2017. ETSS Management, Malaysia.

[4] Akhtar, M. S., Salleh, L. M., \& Mehmood, S. adil. (2017). Conceptualization of Paradoxical Outcomes on Employees' Intention to Stay and Intentions to Leave. Science International, 29(6), 12151218 .

[5] Barbuto, J. E., \& Wheeler, D. W. (2006). Scale Development and Construct Clarification of Servant Leadership. Group \& Organization Management, 31(3), 300-326. https://doi.org/10.1177/1059601106287091

[6] Black, G. L. (2010). Correlational Analysis of Servant Leadership and School Climate. Servant Leadership and School Climate, 13(4), 437-466. https://doi.org/10.1080/13632430220143024

[7] Brohi, N. A., Abdullah, M. M. Bin, Khan, A. M., Dahri, A. S., Ali, R., \& Markhand, K. H. (2018). Communication Quality, Job Clarity, Supervisor Support and Job Satisfaction among Nurses in Pakistan: The Moderating Influence of Fairness Perception. International Journal of Academic Research in Business and Social Sciences, 8(5), 1-6. https://doi.org/10.6007/IJARBSS/v8-i5/4078

[8] Brohi, N. A., Jantan, A. H., Sobia, Akhtar, M. S., \& Pathan, T. G. (2018). Does Servant Leadership Style Induce Positive Organizational Behaviors? A Conceptual Study of Servant Leadership, Psychological Capital, and Intention to Quit Relationship. Journal of International Business and Management, 1(1), 1-15.

[9] Brohi, N. A., Pathan, T. G., Khuhro, M. A., Mahmood, S. A., Akhtar, M. S., \& Tee, K. K. (2016). Do They Exist? An Empirical Study of New Human Resource Roles. In INTERNATIONAL CONFERENCE ON ENGINEERING, TECHNOLOGIES AND SOCIAL SCIENCES 2016 (ICETSS 2016), KUALA LUMPUR MALAYSIA.

[10] Brohi, N. A., Pathan, T. G., Khuhro, M. A., Mehmood, S. A., Akhtar, M. S., \& Tee, K. K. (2017). An Empirical Study of Contemprory HR Roles in Malaysian Context. Science International, 29(6), 1207-1214.

[11] Chan, S. C. H., \& Mak, W. (2014). The impact of servant leadership and subordinates' organizational tenure on trust in leader and attitudes. Personnel Review, 43(2), 272-287. https://doi.org/10.1108/PR-08-2011-0125
[12] Chiniara, M., \& Bentein, K. (2016). Linking servant leadership to individual performance: Differentiating the mediating role of autonomy, competence and relatedness need satisfaction. The Leadership Quarterly, 27(1), 124-141. https://doi.org/10.1016/j.leaqua.2015.08.004

[13] Cotton, J. L., \& Tuttle, J. M. (1986). Employee Turnover: A MetaAnalysis and Review with Implications for Research. The Academy of Management Review, 11(1), 55. https://doi.org/10.2307/258331

[14] Dries, N. (2013). The psychology of talent management: A review and research agenda. Human Resource Management Review, 23(4), 272-285. https://doi.org/10.1016/j.hrmr.2013.05.001

[15] Edmondson, A. C. (1999). Psychological safety and learning behavior in work teams. Administrative Science Quarterly, 44(2), 350 352. https://doi.org/10.2307/2666999

[16] Edmondson, A. C., \& Lei, Z. (2014). Psychological safety: The history, renaissance, and future of an interpersonal construct. Annual Review of Organizational Psychology and Organizational Behavior, 1, 23-43. https://doi.org/10.1146/annurev-orgpsych-031413091305

[17] Fuller, J. B., Morrison, R., Jones, L., Bridger, D., \& Brown, V. (1999). The effects of psychological empowerment on transformational leadership and job satisfaction. Journal of Social Psychology, 139(3), 389-391. https://doi.org/10.1080/00224549909598396

[18] Greenleaf, R. K. (1970). Who is the Servant-Leader? International Journal of Servant-Leadership, p17-22. https://doi.org/10.2307/2086496

[19] Gregory Stone, A., Russell, R. F., \& Patterson, K. (2004). Transformational versus servant leadership: a difference in leader focus. Leadership \& Organization Development Journal, 25(4), 349-361. https://doi.org/10.1108/01437730410538671

[20] Griffeth, R. W., Hom, P. W., \& Gaertner, S. (2000). A metaanalysis of antecedents and correlates of employee turnover: Update, moderator tests, and research implications for the next millennium. Journal of Management, 26(3), 463-488. Retrieved from http://www.scopus.com/inward/record.url?eid=2-s2.00000203435\&partnerID $=$ tZOtx3y1

[21] Hoch, J. E., Bommer, W. H., Dulebohn, J. H., \& Wu, D. (2016). Do Ethical, Authentic, and Servant Leadership Explain Variance Above and Beyond Transformational Leadership? A Meta-Analysis. Journal of Management, XX(X), 14920631666546. https://doi.org/10.1177/0149206316665461

[22] Hom, P., Lee, T. W., Shaw, J. D., \& Hausknecht, J. P. (2017). One Hundred Years of Employee Turnover Theory and Research. Journal of Applied Psychology, (765), 1-35. https://doi.org/10.1037/ap10000103

[23] Hunter, E. M., Neubert, M. J., Perry, S. J., Witt, L. A., Penney, L. M., \& Weinberger, E. (2013). Servant leaders inspire servant followers: Antecedents and outcomes for employees and the organization. Leadership Quarterly, 24(2), 316-331. https://doi.org/10.1016/j.leaqua.2012.12.001

[24] Kahn, W. A. (1990). Psychological Conditions of Personal Engagement and Disengagement At Work. Academy of Management Journal, 33(4), 692-724. https://doi.org/10.2307/256287

[25] Kashyap, V., \& Rangnekar, S. (2016). Servant leadership, employer brand perception, trust in leaders and turnover intentions: a sequential mediation model. Review of Managerial Science, 10(3), 437461. https://doi.org/10.1007/s11846-014-0152-6

[26] Krog, C. L., \& Govender, K. (2015). The relationship between servant leadership and employee empowerment, commitment, trust and innovative behaviour: A project management perspective. SA Journal of Human Resource Management, 13(1), 1-12. https://doi.org/10.4102/sajhrm.v13i1.712

[27] Liden, R. C., Wayne, S. J., Meuser, J. D., Hu, J., Wu, J., \& Liao, C. (2015). Servant leadership: Validation of a short form of the SL-28. The Leadership Quarterly, 26(2), 254-269. https://doi.org/10.1016/j.leaqua.2014.12.002

[28] Liden, R. C., Wayne, S. J., Zhao, H., \& Henderson, D. (2008). Servant leadership: Development of a multidimensional measure and multi-level assessment. Leadership Quarterly, 19(2), 161-177. https://doi.org/10.1016/j.leaqua.2008.01.006

[29] Mahembe, B., \& Engelbrecht, A. S. (2014). The relationship between servant leadership, organisational citizenship behaviour and team effectiveness. SA Journal of Industrial Psychology, 40(1), 10 pages. https://doi.org/10.4102/sajip.v40i1.1107

[30] Mehmood, S. A., Nadarajah, D., Akhtar, M. S., Brohi, N. A., \& Khuhro, M. A. (2018). A Conceptual Framework Explaining the Impact of Perceived Career Growth and Organisational Justice on 
Intention to Stay Among City Traffic Police Lahore. International Journal of Engineering and Technology-UAE, 7(33), 22-28.

[31] Miskel, C. G., Fevurly, R., \& Stewart, J. (1979). Organizational Structures and Processes, Perceived School Effectiveness, Loyalty, and Job Satisfaction. Educational Administration Quarterly, 15(3), 97-118. https://doi.org/10.1177/0013131X7901500308

[32] Parolini, J., Patterson, K., \& Winston, B. (2009). Distinguishing between transformational and servant leadership. Leadership \& Organization Development Journal, 30(3), 274-291. https://doi.org/10.1108/01437730910949544

[33] Peter Michael Blau. (1964). Social Exchange. Annual Reviews in $\begin{array}{ll}\text { Anthropology, 6(1), 255-281. } & \text { 6r. }\end{array}$ https://doi.org/10.1146/annurev.an.06.100177.001351

[34] Porter, L. W., Steers, R. M., Mowday, R. T., \& Boulian, P. V. (1974). Organizational commitment, job satisfaction, and turnover among psychiatric technicians. Journal of Applied Psychology, 59(5), 603-609. https://doi.org/10.1037/h0037335

[35] Qureshi, M. A., Brohi, N. A., Qureshi, J. A., Ahmed, A., Dahiri, A. S., \& Pathan, T. G. (2018). Impact of Servant Leadership Style on Moral Identity and Counterproductive Work Behavior: A Moderated Mediation Analysis using SEM-PLS Technique. In 2018 International Conference on Management, Leadership and Business IntelligenceAt: Houston, Texas USA.

[36] Qureshi, M. A., Hamid, K. B. A., Jeihoony, P., Ali, R., Brohi, N. A., Magsi, R., \& Shah, S. M. M. (2018). Is Supervisor Support Matter in Job Satisfaction? a Moderating Role of Fairness Perception Among Nurses in Pakistan. Academy of Strategic Management Journal, 17(6), 1-10.

[37] Reed, L. L., Vidaver-Cohen, D., \& Colwell, S. R. (2011). A New Scale to Measure Executive Servant Leadership: Development, Analysis, and Implications for Research. Journal of Business Ethics, 101(3), 415-434. https://doi.org/10.1007/s10551-010-0729-1

[38] Rodriguez, B. (2016). Reducing Employee Turnover in Retail Environments: An Analysis of Servant Leadership Variables. Walden Dissertations and Doctoral Studies. Retrieved from http://scholarworks.waldenu.edu/dissertations $/ 2758$

[39] Ronald A Lindahl. (2010). Be a better leader, have a richer life. Journal of Leadership Studies, 3(4), 34-45. https://doi.org/10.1002/jls

[40] Russell, R. F., \& Stone, A. G. (2002). A review of Servant Leadership Attributes: Developing Practical Model. Leadership and Organization Development Journal, 23(3), 145-157. https://doi.org/10.1108/01437730210424084

[41] Shah, S. M. M., Ali, R., Dahri, A. S., Brohi, N. A., \& Maher, Z. A (2018). Determinants of Job Satisfaction among Nurses: Evidence from South Asian Perspective. International Journal of Academic Research in Business and Social Sciences, 8(5), 19-26. https://doi.org/10.6007/IJARBSS/v8-i5/4082

[42] Shaw, J., \& Newton, J. (2014). TEACHER RETENTION AND SATISFACTION WITH A. Education, 135(1), 101-106.

[43] Spears, L. C. (2004). Practicing Servant Leadership. Leader to Leader.

[44] van Dierendonck, D., \& Nuijten, I. (2011). The Servant Leadership Survey: Development and Validation of a Multidimensional Measure. Journal of Business and Psychology, 26(3), 249-267. https://doi.org/10.1007/s10869-010-9194-1

[45] Whitaker, T. (2009). What Great Principals Do Differently. Education World, (812), 1. Retrieved from http://www.educationworld.com/a_admin/admin/admin410.shtml 